Cahiers $d u$ MONDE RUSSE

\section{Cahiers du monde russe}

Russie - Empire russe - Union soviétique et États indépendants

$62 / 4 \mid 2021$

Varia

\title{
Sören URBANSKY, Beyond the Steppe Frontier. A History of the Sino-Russian Border
}

\section{Willard Sunderland}

\section{OpenEdition}

\section{Journals}

Electronic version

URL: https://journals.openedition.org/monderusse/12815

DOI: $10.4000 /$ monderusse. 12815

ISSN: $1777-5388$

\section{Publisher}

Éditions de l'EHESS

\section{Printed version}

Date of publication: 1 December 2021

Number of pages: $708-710$

ISBN: 978-2-7132-2895-7

ISSN: $1252-6576$

\section{Electronic reference}

Willard Sunderland, "Sören URBANSKY, Beyond the Steppe Frontier. A History of the Sino-Russian Border", Cahiers du monde russe [Online], 62/4 | 2021, Online since 01 December 2021, connection on 02 September 2022. URL: http://journals.openedition.org/monderusse/12815 ; DOI: https://doi.org/ 10.4000/monderusse. 12815

This text was automatically generated on 2 September 2022.

All rights reserved 


\title{
Sören URBANSKY, Beyond the Steppe Frontier. A History of the Sino-Russian Border
}

\author{
Willard Sunderland
}

\section{REFERENCES}

Sören URBANSKY, Beyond the Steppe Frontier. A History of the Sino-Russian Border,

Princeton : Princeton University Press, 2020, 370 p.

1 The balance of power between China and Russia today, in truth, is not much of a balance at all. The PRC's economy is far larger and more diversified, its influence vastly more global. The Chinese leadership at home is more repressive than Russia's but also more flexible, seemingly more adept at navigating the channels and shoals of contemporary globalization. Finally, for all the understandable eye-rolling in the West about Xi Jinping Thought, the idea of "Putin Thought" seems truly ridiculous. For what it's worth, China is at least proposing a model to the world. Single-party rule + "socialism with Chinese characteristics" + economic dynamism + global outreach = a genuine bid at world leadership. Russia, by contrast, has no model to offer at the moment. It's a petrostate ruled by an oligarchy. What the current Russian leadership seems to do best is mismanage the country's natural and human capital.

2 Yet this is hardly the whole story of Sino-Russian comparisons today and even less a guide to the long history of relations between the two countries. The pendulum that has swung so strikingly to China's side in our time has swung differently in the past, and even in any single historical moment, the seemingly stark power differential between the two states always appears less clear cut when one turns to concrete locations and themes. Sören Urbansky's remarkable book is one of the best guides yet to this more nuanced way of understanding the Sino-Russian relationship. Urbansky doesn't shy from useful generalizations, but his focus is on the fine grain of how the Russians and Chinese 
get along, or don't, in the relatively small but influential contact zone they share along the Argun/E'erguna River.

3 Though only a small portion of the Sino-Russian border overall, the Argun/E'erguna has played a critical role in shaping border politics. Beginning with the Treaty of Nerchinsk/ Nibuchu in 1689, the main course of the river became established as the western boundary between the two states. This was then affirmed by the Kiakhta/Qiaketu Treaty of 1728 , and for the next one hundred and twenty-five years, even as Kiakhta/Qiaketu became the main interchange for Sino-Russian trade, the Argun/E'erguna operated as a contact zone of its own, with Cossacks and Khori Buryats on the Russian side and Manchu officials and various indigenous communities in Chinese territory engaging in limited trade and surveillance along what remained for generations a largely open, uncontrolled, sparsely settled frontier.

4 The great change came in 1903 with the opening of regular traffic on the Chinese Eastern Railroad (CER; Kitaisko-Vostochnaia zheleznaia doroga/Zhongguo Dongsheng tielu), which cut between the two countries just south of the Argun/E'erguna in an area of open steppe that would become the mixed Sino-Russian settlement of Manzhouli/ Man'chzhuriia. The border zone was always more than the railroad, but, nonetheless, from this point on, the railroad would set the terms. As the first station of the CER in Chinese territory, Manzhouli/Man'chzhuriia became the new meeting point between the two states, rapidly eclipsing Kiakhta/Qiaketu, and squarely repositioning the border dynamic in the Argun/E'erguna region.

5 At first a "frontier spirit" prevailed (44). Manzhouli/Man'chzhuriia popped into being as a boom town of cheap hotels, bordellos, and a great deal of cross-cultural mixing and practical traffic, including of smuggled gold and staggering volumes of illegal liquor known in border pidgin as khanshin. As one observer put it, "If all the...alcohol [moving through here] were imbibed by the locals, this village would surely be the most drunken [place] on the planet." (59) At the same time, however, even with all the booze escaping state control, state control was nonetheless being imposed. Customs houses quickly appeared as did passport checks, quarantine wards, and veterinary stations, followed, in time, by observation towers, barbed wire, border wars, and hardening assumptions about "us" versus "them." By the 1930s formerly Sino-Russian Manzhouli/Man'chzhuriia had become Japanese-occupied, mostly Chinese Manzhouli. By the 1950s, the Soviets built up their own militarized outpost on their side of the border at Zabaikal'sk (formerly Otpor).

6 In this regard, at least, Urbansky's story is not entirely surprising. Much as in countless other places around the world, what begins as a porous frontier becomes a hard border, which then seems to steadily tighten as the twentieth century grinds on. But if this is the predictable overall arc of the tale, Urbansky's fine-grain approach allows him to expose numerous meaningful complexities, the most important being that the border, in fact, does not always tighten - sometimes it falls apart. In this case, it falls apart three times: first during the chaotic interregnum of the Chinese and Russian revolutions, then again during World War II, and then once more during the ungluing of the USSR, followed in each case by a new reconstitution. Indeed, even if the border is hardening again in our day, Urbansky's main lesson seems to be that we shouldn't expect it to remain this way forever.

7 Another lesson is that state borders are not just made or unmade by states; they're also defined by the "borderlanders" who live around them. Indeed, one of the pleasures of Urbansky's book is the chance every now and then to hear what ordinary border 
residents think and, in the process, to be reminded of their agency in the border-shaping exercise. For example, in the last pages of the work, when he asks one local Russian whether she has ever been to the Chinese side, she tells him: "To tell you the truth, I'm not interested... Everything I need I can purchase here. And if I really want to see what Manzhouli looks like, I can turn on my television." (269) One wonders whether any state official, Soviet or Maoist, Qing or Romanov, could ever dream up a better way to make a border than that.

Anthropologists might wish Urbansky had inserted more voices like this into his narrative. Some historians might wish he had done the opposite - that he'd drawn down the local agency and beefed up the geopolitics, or at least offered more reflection on possible connections between the two. Some geographically exact readers might point out, despite the title, that this isn't "a history of the Sino-Russian border" but rather just a small part of it. Finally, some lovers of short books will sigh that, for all of its many qualities, this is a rather long one.

But, all of this said, knowing that there is no such thing as a perfect book, Urbansky's for me comes close enough. The picture here is so rich, so full of fascinating and, at times, dazzling detail, offered frequently from both sides of the line, drawing on Russian and Chinese sources, and reflecting the shifting perspectives of Russian, Chinese, Japanese, and various Siberian and Mongolian actors, that there is no reason not to be grateful for the book just the way it is. Writing the history of the Sino-Russian border is challenging, in part due to these multicultural complexities and in part to the suspicions and secrecy that shroud the border experience, but Urbansky has done so masterfully. And he's included some good pictures, too.

\section{AUTHORS}

\section{WILLARD SUNDERLAND}

University of Cincinnati, National Research University Higher School of Economics, Moscow 